\title{
Analyzing the Religious Music Lessons Taught in Imam Hatip High Schools in Terms of Quantity and Quality*
}

\author{
Özkan Apaydin ${ }^{1}$ \\ Ankara University
}

\begin{abstract}
This study has been performed with the aim of providing reorganization of the Religious Music course as a compulsory course in Imam Hatip High Schools' weekly course programs in order for students and teachers to be able to use the curriculum and course books functionally, as well as providing the "Imam Hatip Religious Staff" of the future with the ability to perform our religious services properly in an aesthetic and musical sense. By determining the current situation of the Religious Music course in Imam Hatip High Schools, this study measures students' attitudes toward the class, applies a questionnaire to the teachers, and examines the book used in class in detail using the descriptive method (scanning). Results from the Attitude toward the Music Lesson Scale have been analyzed using the SPSS program; student-teacher views and suggestions have also been reviewed. The problems seen in the course book have also been addressed together by way of solutions. The study carries a unique feature both in terms of addressing the condition of the course by way of "curriculum, student, teacher, and book," and revealing current problems using scientific scales, as well as in terms of presenting ways to solve these problems through scientific methods by referencing student and teacher views. In the study, books written on religious music lessons, history, and education; doctoral dissertations and theses; articles; course books that have been taught and that are taught even today; the Ministry of National Education's memorandums, regulations, and board decisions; and student/teacher views from the sample of selected schools form the basic resources of the study.
\end{abstract}

\section{Keywords}

Imam Hatip High Schools • Religious music education • Islam and traditional music • Student attitudes •

Music education

\footnotetext{
* This is an extended abstract of the paper entitled "İmam-Hatip Liselerinde Okutulan Dinî Mûsikî Dersinin Nicelik ve Nitelik Bakımından İncelenmesi" published in Talim: Journal of Education in Muslim Societies and Communities.

Manuscript Received: November 22, 2017 / Revised: December 23, 2017 / Accepted: January 4, 2018 / OnlineFirst: February $20,2018$. 1 Özkan Apaydın (PhD), Ankara University, Institute of Social Sciences, Ankara Turkey. Email: aranje44@gmail.com

To cite this article: Apaydın, Ö. (2017). Analyzing the religious music lessons taught in Imam Hatip High Schools in terms of quantity and quality. Talim: Journal of Education in Muslim Societies and Communities, 1, $219-256$. http://dx.doi.org/10.12738/talim.2017.2.0008
} 
The history of the Imam Hatip High School (IHH) goes back as far as the Ottoman Empire. Religious lessons are seen to weigh heavily in these schools' teaching programs, which all students who want an education with emphasis on religion can choose, in addition to those who want to be Imams, preachers, and religious officials. These schools provide services in connection with the General Directorate of Religious Education, which is affiliated with the Ministry of National Education (MoNE). If one considers the fact that the number of IHH students during the 2015-2016 school year was approximately 700,000, saying this many students will not choose a profession outside of religious officials, imams, and so on would be unrealistic. One of the most important factors increasing the attractiveness of these schools is their peaceful educational environment (Ünsür, 2005, p. 243). If one analyzes the weekly lesson program of IHHs, whose numbers are increasing rapidly, numerical and verbal lessons are seen to take place intensively within the program together with vocational courses (MoNE, 2014a). This is because studying in these schools are students who are predicted to choose professional groups such as district governors, officials, lawyers, teachers, engineers, architects, police, and so on. That some of the students studying at IHHs are graduates of Imam Hatip Middle Schools while others are graduates of middle schools that provide normal education is one of the difficulties experienced in the sense of IHHs' student-readiness. The constant changes being performed in the course programs taught at IHH adversely affect the functionality of education given at the schools. In particular, by removing from the course schedule the art-content courses that students feel the most need practically in their professional lives, like music and religious music, having artistic courses be faced with the danger of extinction is thought provoking. In reducing the duration of these courses year after year by bringing compulsory music lessons to an elective status from among physical education and visual arts classes, it is slowly being pushed into an extinction process (MoNE, 2014b). The fact that Religious Music, one of these art classes, is an elective course also reduces, and even eliminates in the vast majority of cases, the possibility of IHH students' being able to benefit from artistic classes. However, IHH students have a need for artistic classes. Art is a necessity for everyone. Art is a societal need, one of the reasons for humans to exist (Uçan, 2005, p. 172). Aside from this, the existence of the religious music course in the education program, though as an elective class, and of a book related to this course have been assessed as situations that can be encountered positively among these negatives.

\section{Method}

In this study, the problems of the course are discussed by arriving at the essence using a deductive approach. The process of the research model is collection, analysis, interpretation, and reporting (writing) of the data by planning to solve the detected problems. Accordingly, it is based on the descriptive (scanning) method in the 
framework of screening toward identifying the situation with the purpose of revealing the general situation of the Religious Music course taught at IHHs by investigating students' attitudes, teachers' views, and the coursebook (Şimşek \& Yıldırım, 2005, p. 47). Through this model, identifying the current situation and qualities of the problem has been attempted as the subject of research.

\section{Universe and Sample of the Study}

The universe of this study is formed from: students studying at the Nallihan, Bâlâ, Kalecik, and Demetevler Anatolian Imam Hatip High Schools located in Ankara that provide education in affiliation with the Ministry of National Education, the teachers who enter the Religious Music class in these schools, the coursebook for Religious Music as taught in the classes, and 9th-, 10th-, 11th-, and 12th-grade students studying in schools from among the sample who elected the religious music course. Two reasons exist for having chosen these schools as the sample. The first is to not remain bound to schools found just in the center of Ankara, and the second is, because the religious music course is an elective, the number of schools offering this course is limited. Offering the physical education course in place of the religious music course in the majority of central Ankara schools that are very populated and have good facilities has created difficulty on the topic of choosing a sample.

\section{Data Collection Tools}

Data has been collected in this study by applying the Attitude Scale Related to the Music Course, prepared by Ayfer Kocabaş, to students for the purpose of identifying their attitudes on the Religious Music course. A total of 30 questions are found that form this scale. Percentage distributions from the answers to these questions are shown as pie charts in findings section. The information provided as S1 through S30 are expressed as the questions asked on the scale and answers given. As an example, S1 means Question 1 and this abbreviation has been used for the average percentage of answers given to Question 1 on the attitude scale.

\section{Data Analysis}

In order to be able to identify student attitudes, the Attitude Scale Related to the Music Course was applied to 101 students studying at schools chosen as the sample, and the collected data was analyzed using the analysis programs of Statistical Package for Social Sciences (SPSS 20) and AMOS18. The statistical level of significance has been identified as $p<.05$ in general analyses. This means that when true, there is a .05 probability of rejecting the equality hypothesis. In other words, significant findings in this study have a $95 \%$ confidence interval $(C I)$. Exploratory factor analysis ${ }^{2}$ was

2 Statistical analysis performed for the purpose of finding common variables underlying a large set of variables. 
performed first for the 30 questions prepared for the Attitude Scale Related to the Music Course. Principal component analysis was performed using the varimax method from orthogonal rotations. The Kaiser-Meyer-Olkin $(K M O)$ results show the sample size for this analysis to be at a sufficient level. The result of $K M O=0.848$ as obtained in these analyses is an "excellent" value according to Field $(2009$, p. 81). Bartlett's test of sphericity results $\left(\chi_{(435)}^{2}=1449.894, p<.001\right)$ indicate the correlation among factors to be adequate for analyzing the main components.

\section{Findings}

In the study results, the schools identified as the sample have been detected as generally having positive attitudes towards the religious music course. Demetevler IHH students who had been selected as the sample were identified as having more positive attitudes toward the course compared to the attitudes of students studying in the other sampled schools; the attitudes of students studying in Nallihan IHH were identified as the most negative attitudes among the sampled schools. While, apart from the Nallihan IHH students, a large portion of students studying at the other sampled schools want to increase the religious course class hours in the weekly course program; the majority of Nallhhan IHH students were of the opinion that a course for the Higher Education Transition Exam (YGS) should be in the curriculum in place of the religious music course.

The main reason underlying Nallıhan Imam Hatip students' attitudes toward the religious music course being in a negative state as an unnecessary class is thought to be that the field of the teacher entering the class is not "music." At the same time, reasons such as the school having no music room or musical instruments and the coursebook being dysfunctional and not for students are also thought to influence student attitudes; however, the most important reason is thought to originate from the field of the teacher entering class not being in music. In the same way, Demetevler IHH students' attitudes being the most positive and a portion of the students suggesting the opinion of wanting to increase the religious music course's weekly lesson hours is thought to source from reasons such as having a few permanent music teachers at the school; teachers not sticking to just the coursebook; the school having a music room and instruments like the org, ney, guitar, and bağlama; and providing additional education on these instruments to students in the scope of a "training course" for those who want.

\section{Discussion and Result}

In this study, the result has been revealed that the Religious Music course in IHHs fits in among the courses that students want. From this perspective and by considering the interests, wants, and expectations of IHH students who have a very 
large role to undertake in building the future, having religious music classes be at least two hours a week and among the compulsory classes, implementing by planning in-service trainings that the course teachers want and feel are needed, reorganizing the course book, improving the physical possibilities of the class, and having the materials related to the class meet clear standards in all IHHs have been revealed as necessary. When considering that students need to benefit more from each and every science that they themselves will require, particularly in religious matters (Zernucci, 2011, p. 83), the importance of this course is not considered sufficiently understood because the religious music course also comes at the start of these classes.

Regarding what students have said, the Religious Music course taught in IHHs needs to: be at least two hours a week and compulsory, have the physical possibilities related to the class transformed into a standard structure, have materials related to the class improved, and also prepare the coursebook used in class according to the principle of student relativity. In arriving at the educational goals, if the most important role is also seen as the teacher, the main educational programs need to be prepared in a way that will include the wants and expectations of the students who will receive this education. That which targets an educational program that does not respond to students' interests, wants, or expectations appears unable to achieve success.

The importance of performing studies with consciousness and sensitivity to the important tasks to be undertaken in building the future and to IHHs and all Imam Hatip Schools' course schedules, curriculum, teaching programs, materials, and teacher in-service trainings with the awareness that the success of IHH students will be the success of Turkey needs to be understood by all authorities (Onural, 2005, p. 81). Developing teacher adequacy is one of the greatest requirements because teachers are the most important professional group not just for IHH students, but also in developing and raising awareness in all of society (Aydın, 2003, p. 69). The prominence of this issue is even greater in a class that requires a special talent area like religious music. The cornerstone of education, its main center, is the teacher (Adem, 1997, p. 187). Therefore, the teacher factor should not be ignored in the religious music course, and teachers, especially those entering the Religious Music course in IHHs, need to have new regulations in their undergraduate programs. If one wants to reach the desired goals in the educational environment, teachers need to be provided with all the necessary possibilities, including in-service training. The success of institutions is held in the available strategies and roadmaps connected to these (Aksu, 2001, p. 3).

As a result, certain elements exist that determine the quality of education in the educational environment, and each element has its own unique importance. All the elements described in this study need to be in place in order for the Religious Music course to achieve the goals that it aims for. Cultivating this understanding and 
philosophy within our youths, our most important stakeholders in building the future, will surely be the greatest goal and expectation. Students have the right to receive the best education. Schools are obliged to respond to students' requirements (Kalayc1, 2005, p. 149). Having all related departments and officials who are authorized and responsible on this topic show the necessary precision is seen as important for the growth of the Turkish government and nation. 